\title{
Йодо- та селенодефіцит у патогенезі зобної трансформації щитоподібної залози та автоімунних тиреопатій (огляд літератури та результати власних досліджень)
}

Ю.М. Таращенко, А.Є. Коваленко, В.І. Кравченко, О.І. Ковзун, O.B. Сімуров

ДУ «Інститут ендокринології та обміну речовин ім. В.П. Комісаренка НАМН України»

Резюме. У статті описано сучасний погляд на роль дефіциту йоду та селену в патогенезі захворювань щитоподібної залози (ЩЗ), зокрема їі зобної трансформації та автоімунних тиреопатій. Відмічена кореляція вираженості патологічних змін зі ступенем йододефіциту. У зонах зниженого споживання йоду (<50 мкг на добу) 2530\% населення мають ту чи іншу патологію ЩЗ, серед яких найчастішою є ендемічний зоб. Другою за частотою виникнення патологією ЩЗ є вузловий зоб, частота якого в ендемічних по зобу регіонах досягає 50-70\% від усіх захворювань Щ3. Поєднаний дефіцит йоду і селену посилює проблему йодної недостатності, призводить до зростання частоти гіпертрофічних і гіперпластичних процесів у Щз і автоімунних тиреопатій. Метою роботи було визначення вмісту йоду та селену в пацієнтів із доброякісною патологією ЩЗ. Матеріал і методи. Обстежено 81 пацієнта, віком від 19 до 69 років, яким проводили ультразвукове обстеження ЩЗ, визначали рівень екскреції йоду зі сечею церій-арсенітним методом у модифікації J.T. Dunn та ін. і рівень селену в сироватці крові спектрофлуориметричним методом. Результати. У 43,6\% пацієнтів при різних видах зобної трансформації, колоїдному проліферуючому зобі, автоімунних тиреопатіях та їх поєднанні відзначено низький рівень йодної екскреції (<100 мкг/л); у 38,5\% пацієнтів виявлено стабільно оптимальне йодне забезпечення (100-150 мкг/л) і в 17,9\% пацієнтів — стабільно високе (>150 мкг/л). У 76,5\% пацієнтів виявлено значно знижений рівень селену в крові (<80 мкг/л), у 13,6\% пацієнтів - субоптимальний (81-100 мкг/л) і лише в 9,9\% пацієнтів - оптимальний (101-120 мкг/л). Також відзначено, що в пацієнтів із вузловою патологією Щ3, автоімунними тиреопатіями та при їх поєднанні зафіксовано дефіцит селену в порівнянні з контрольною групою (ехографіч-

\footnotetext{
* Адреса для листування (Correspondence): ДУ «Інститут ендокринології та обміну речовин ім. В.П. Комісаренка НАМН України», вул. Вишгородська, 69, м. Київ, 04114 україна. E-mail: zdovado@ukr.net
} 
Оригінальні дослідження

но незмінена Щ3). Висновок. Терапія препаратами йоду та селену під контролем їх вмісту виправдана в процесі тривалого спостереження за пацієнтами із зобною трансформацією Щз і автоімунними тиреопатіями.

ключові слова: йод, селен, дефіцит мікроелементів, патологія щитоподібної залози, вузловий зоб, ендемічний зоб, ультразвукове дослідження.

\section{Йододефіцит і патогенез зобної трансфор- маціі}

На початку XX століття американський патолог David Marin уперше обгрунтував зв'язок між йодним дефіцитом і гіперпластичними процесами в Щ3, а також описав гістологічні зміни, характерні для ендемічного зобу [1].

Йод $є$ складовою частиною тиреоїдних гормонів (ТГ) - тироксину і трийодтироніну, регулятором гормоногенезу і проліферації тиреоцитів. В умовах дефіциту йоду знижуються синтез і секреція ТГ, що за принципом зворотного зв'язку призводить до підвищення секреції тиреотропного гормону (ТТГ) гіпофізом. Внаслідок ТТГ-залежної стимуляції ЩЗ захоплює з крові все більшу кількість екзогенного йоду, що надходить в організм з їжею і водою, і оптимізує повторне використання ендогенного елементу, включаючи компенсаторні механізми для забезпечення ефективного синтезу ТГ.

Формування різних форм зобної трансформації Щ3 є компенсаторною реакцією, спрямованою на підтримку постійної концентрації ТГ в організмі. Після виснаження функціональних компенсаторних механізмів під впливом ТТГ розвиваються прояви явного або субклінічного гіпотиреозу, з'являються морфологічні ознаки патології ЩЗ - гіпертрофія (збільшення в розмірах) і гіперплазія (збільшення кількості фолікулярних клітин), а з часом функціональна автономія і злоякісність [2, 3].

Патогенез гіпертрофії Щ3 в результаті йодного дефіциту досить складний. За своєю суттю, формування зоба є компенсаторною реакцією, спрямованою на підтримку постійної концентрації ТГ в організмі в умовах йодного дефіциту. За сучасними уявленнями, теорія гіперпродукції або підвищеної чутливості тиреоцитів до ТТГ не може повністю пояснити патогенез йододефіцитного зоба, а проліферативні і трофічні ефекти ТТГ часто опосередковані іншими чинниками. Зокрема, зниження вмісту йоду в тканині ЩЗ призводить до посиленої продукції факторів росту, серед яких найбільш значимими є інсуліноподібний фактор росту 1-го типу, епідермальний фактор росту, фактор росту фібробластів і трансформуючий фактор росту $\beta$.

Показано, що зростання ізольованих фолікулів ЩЗ, що містять достатню кількість йоду, не вдається стимулювати введенням ТТГ. Крім того, виявилося, що при блокаді рецепторів інсуліноподібного фактора росту 1-го типу специфічними антитілами ТТГ не здатний чинити трофічні ефекти на тиреоцити [4].

Дефіцит йоду активує інтратиреоїдні медіатори проліферації і фактори росту: інтерлейкіни, інсуліноподібний фактор росту 1-го типу, епідермальний фактор росту, а також інозитолтрифосфат - один із найпотужніших внутрішньоклітинних факторів проліферації. Доведено, що утворення зоба відбувається під впливом інтратиреоїдних чинників росту, а за нормальної концентрації йоду в ЩЗ ТТГ не стимулює іï гіпертрофію [5]. Чим сильніше знижується вміст йоду в ЩЗ, тим більше активізуються інтратиреоїдні чинники росту. Спочатку це призводить до дифузного збільшення Щ3, яка за рахунок напруги компенсаторних механізмів підтримує рівень ТГ у межах норми. При тривалому дефіциті йоду компенсаторні механізми виснажуються, що призводить до утворення як доброякісних, так і злоякісних вузлів. Крім того, в умовах дефіциту йоду може порушитися функція ЩЗ, розвинутися гіпотиреоз - зниження здатності Щ3 синтезувати ТГ (мало сировини (йоду) - мало гормонів), або тиреотоксикоз - підвищення 
здатності ЩЗ до автономного неконтрольованого синтезу ТГ у вузлах ЩЗ - тиреотоксичних аденомах або багатовузловому токсичному зобі. Останній є закономірним результатом дефіциту йоду протягом тривалого часу.

Йодне забезпечення визначається за вмістом йоду в сечі (йодурія) і за даними Всесвітньої організації охорони здоров’я може бути [6]:

- оптимальним - 100-200 мкг/л;

- більш ніж достатнім ->200-300 мкг/л;

- надмірним - >300 мкг/л;

- недостатнім легкого ступеня 50-99 мкг/л;

- недостатнім середньої важкості 20-49 мкг/л;

- недостатнім важкого ступеня $<20$ мкг/л.

\section{Йододефіцитні захворювання Щ3}

Захворювання, що виникають внаслідок нестачі йоду в організмі, включають зоб, гіпотиреоз, безплідність, викидні, мертвонароджуваність, вроджені аномалії, підвищену перинатальну і дитячу смертність, кретинізм, затримку фізичного та розумового розвитку, порушення психічних функцій у дітей і дорослих, зниження працездатності, підвищену чутливість до іонізуючого опромінення тощо [711]. У зонах зниженого споживання йоду ( $<50$ мкг на добу) 25-30\% населення мають ту чи іншу патологію ЩЗ, серед яких найчастішою є ендемічний зоб. Другою за частотою виникнення патологією ЩЗ є вузловий зоб, частота якого в ендемічних по зобу регіонах досягає 50-70\% від усіх захворювань Щ3 [12].

Йодний дефіцит і вузлові форми колоїдного проліферуючого зоба

Тиреоцити початково не є ідентичними за своєю проліферативною активністю, що позначається як мікрогетерогенність: одні тиреоцити більш активно захоплюють йод, інші більш активно продукують ТГ, треті - більш активно діляться, четверті - мають початково низьку функціональну і проліферативну активність.

В умовах йодного дефіциту ЩЗ знаходиться під впливом хронічної гіперстимуляції, основною причиною якої є зниження інтратиреоїдного пулу йоду. На першому етапі ця гіперстимуляція призводить до дифузного збільшення всієї ЩЗ - утворюється дифузний еутиреоїдний зоб. У зв’язку з тим, що йодний дефіцит призводить до гіперстимуляції всієї ЩЗ, процес вузлоутворення, як правило, не обмежується однією ділянкою або часткою у результаті утворюється багатовузловий зоб. Незважаючи на локальність проявів (часто тільки один вузол), вузловий зоб у пацієнтів, що проживають у йододефіцитному регіоні, за своєю суттю, є захворюванням усього органу. Це має велике клінічне значення, оскільки пояснює високу частоту післяопераційних рецидивів вузлового зоба за відсутності профілактичної терапії препаратами йоду.

Слід зазначити, що на ранніх етапах вузловий зоб не веде до порушення функції ЩЗ. Однак, у окремих пацієнтів можуть сформуватися вузлові утворення, що призводять у подальшому до функціональної автономії ЩЗ і розвитку тиреотоксикозу $[13,14]$.

\section{Функціональна автономія Щ3}

Під функціональною автономією ЩЗ розуміють незалежну від регулюючих впливів гіпофіза продукцію ТГ. На тлі мікрогетерогенності тиреоцитів і в умовах хронічної гіперстимуляції ЩЗ спостерігається прискорене зростання серед клітин із найбільшим проліферативним потенціалом. Активний поділ тиреоцитів призводить до гальмування репаративних процесів у генетичному апараті клітин із наступним утворенням соматичних мутацій. Мутації, що призводять до автономного функціонування тиреоцитів, позначаються як активуючі. Cеред активуючих мутацій тиреоцитів найбільш відома мутація рецептора ТТГ, що призводить до його стійкої активації навіть за відсутності ліганду, а також мутація $\alpha$-субодиниці Gs-білка каскаду ТТГ-цАМФ, яка також стабілізує його в активному стані.

Із роками, за умови збереження йодного дефіциту, число автономно функціонуючих тиреоцитів збільшується. Найчастіше вони групуються у вузлові утворення (монофокальна або мультифокальна форма функціональної автономіі), але приблизно у 20\% випадків дисеміновано розсіяні по всій ЩЗ. Крайнім проявом функціональної автономії ЩЗ є вузловий або частіше багатовузловий токсичний зоб [15].

Селен і захворювання щ3

Селен було відкрито шведським хіміком J.J. Berzelius у 1817 році. Селен є облігатним 
мікронутрієнтом, який надходить в організм через кишечник і накопичується в печінці, нирках і м'язовій тканині. Селен бере участь у синтезі, активації і метаболізмі ТГ, а його дефіцит призводить до загибелі тиреоцитів і заміщенню паренхіми ЩЗ сполучною тканиною.

Щ3 є одним з органів із високим вмістом селену, який утворює в ній селенопротеїни - активні біоантиоксиданти [16, 17]. Крім того, селен може проявляти протипухлинну активність через декілька потенційних механізмів, що включають індукцію апоптозу, антиоксидантну дію, зміну метилювання ДНК генів-супресорів пухлини, стимуляцію імунної системи за рахунок протизапальних та антиангіогенних властивостей [18]. Відмічено покращення клінічного перебігу хронічного автоімунного тиреоїдиту в пацієнтів, яким була проведена компенсація дефіциту селену. Водночас, можливі мутації в генах, які кодують синтез селенопротеїдів, із наступним розвитком дефіциту селену [19].

Дефіцит селену супроводжується зниженням імунітету, посиленням несприятливих вільнорадикальних процесів, ризиком активації тиреоїдних автоімунних реакцій, порушенням конверсії тироксину в трийодтиронін. У результаті додавання в раціон сполук селену (у формі селеніту або селената натрію) відбувається пригнічення запалення і зниження титрів антитіл при автоімунному тиреоїдиті. Виявлено патогенетичний взаємозв'язок між окремими випадками гіпотиреозу в дітей та селеновою недостатністю [20]. Відзначено роль дефіциту селену в патогенезі багатовузлового колоїдного зоба.

У ряді досліджень показана позитивна динаміка зниження титрів антитіл до тиреоїдної пероксидази в пацієнтів із хронічним автоімунним тиреоїдитом, які отримували селен у фізіологічних дозах - близько 80 мкг на день протягом 6-12 місяців [21, 22].

У профілактиці та терапії йододефіцитних станів слід враховувати нерозривний зв'язок метаболізму йоду 3 метаболізмом інших мікроелементів, у першу чергу селену, як основного молекулярного синергіста йоду, що має важливе значення у функціонуванні ЩЗ. На сьогодні достовірно встановлено, що дефіцит селену є одним із факторів розвитку тиреопатій. Зниження рівня селену в сироватці крові асоціюється 3 такими патологічними змінами Щ3, як збільшення об'єму, зміна ехогенності, наявність вузлових або колоїдних утворень і лімфоїдної інфільтрації. Крім того, селен бере участь в антиоксидантному захисті тиреоцитів i активації ТГ, регулює процеси апоптозу.

В експерименті показано, що навіть в умовах достатнього надходження йоду тривалий дефіцит селену призводить до некрозу і фіброзу залозистої тканини ЩЗ. В умовах селенодефіциту зростає цитотоксична дія перекису водню, як побічного продукту синтезу ТГ, на тканину Щ3. Вплив цього патологічного фактора може провокувати зростання титру антитіл до тиреоїдної пероксидази і антитіл до тиреоглобуліну і в кінцевому рахунку призводить до розвитку автоімунних тиреопатій [23-25].

Одним із найбільш прийнятних способів виявлення забезпеченості організму селеном $є$ визначення його вмісту в сироватці крові. Аналіз публікацій показав значні розбіжності у визначенні добової потреби людини в селені. За рекомендацією Управління з контролю якості харчових продуктів i медикаментів в США (Food and Drug Administration, USA) в організм дорослої людини має надходити в середньому 70 мкг/добу селену для чоловіків і 55 мкг/добу - для жінок. При оптимальній забезпеченості селеном концентрація мікроелемента в сироватці крові становить 115-120 мкг/л, а дефіцит селену проявляється при концентраціях нижче 80 мкг/л. Більшістю дослідників величина до 350-400 мкг розглядається як безпечна добова доза селену [26].

Сполуки селену можуть бути використані 3 лікувальною метою в пацієнтів 3 автоімунними захворюваннями ЩЗ - хронічним автоімунним тиреоїдитом (XAIT), дифузним токсичним зобом, ендокринною офтальмопатією і післяпологовим тиреоїдитом.

Поєднаний дефіцит йоду і селену посилює проблему йодної недостатності, що знаходить своє відображення в структурі захворюваності тиреоїдною патологією у населення України. Зараз ми спостерігаємо зростання не тільки гіпертрофічних і гіперпластичних процесів у ЩЗ, але й автоімунних тиреопатій. Виходячи 3 фізіологічної важливості поєднання йоду і селену для нормальної роботи всіх систем організму, а особливо ї синергічної ролі у функціонуванні ЩЗ, в умовах природного 
дефіциту може бути рекомендовано додатковий лікувально-профілактичний прийом цих мікроелементів.

Мета роботи - визначення рівня йоду в сечі і селену в плазмі крові у пацієнтів із різними варіантами зобної трансформації ЩЗ і автоімунними тиреопатіями, а також оцінка значимості йодо- та селенодефіциту в патогенезі цих захворювань.

\section{Матеріал і методи}

Обстежено 81 пацієнта із захворюваннями Щ3 (вузлові форми зоба, XАIT та їх поєднання), які спостерігаються у відділі хірургї̈ ендокринних залоз ДУ «нститут ендокринології та обміну речовин ім. В.П. Комісаренка НАМН України». Співвідношення чоловіків та жінок становило 1:10,5; середній вік хворих -40 років.

Визначення вмісту йоду в сечі проводили церій-арсенітним методом у модифікації J.T. Dunn та ін. [27]. Референтні діапазони вмісту йоду в сечі були оцінені в трьох варіантах - низький рівень йодної екскреції, йододефіцит (<100 мкг/л), стабільно оптимальне йодне забезпечення (100-200 мкг/л) і стабільно високий рівень йодної екскреції (>200 мкг/л).

Дослідження концентрації селену в сироватці крові пацієнтів проводили спектрофлуориметричним методом [28]. Референтні діапазони концентрації селену в сироватці крові були оцінені в трьох варіантах - знижений (<80 мкг/л), субоптимальний (81-100 мкг/л), оптимальний (101-120 мкг/л).

Статистичний аналіз проводили за допомогою розрахунку критерію Пірсона. Статистично вірогідними вважали відмінності при $\mathrm{p}<0,05$.

До початку роботи було отримано позитивне рішення Комісії з медичної етики ДУ «Інститут ендокринології та обміну речовин ім. В.П. Комісаренка НАМН України» і інформовані згоді від усіх обстежених.

\section{Результати та обговорення}

Серед усіх обстежених пацієнтів $(\mathrm{n}=81)$ у більшості з них (62 особи або 76,5\%) виявлено значно знижений рівень селену в крові.
У 11 спостереженнях (13,6\%) відзначена субоптимальна концентрація селену і тільки у 8 осіб (9,9\%) рівень селену був оптимальним.

За всіх клініко-патологічних формах 3обної трансформації, колоїдному проліферуючому зобі, автоімунних тиреопатіях та їх поєднанні відзначався дефіцит селену порівняно

Таблиця 1. Розподіл пацієнтів із захворюваннями Щз за вмістом селену в сироватці крові

Table 1. Distribution of patients with thyroid diseases by serum selenium content

\begin{tabular}{|c|c|c|c|}
\hline \multirow[t]{2}{*}{$\begin{array}{l}\text { Група } \\
\text { Group }\end{array}$} & \multicolumn{3}{|c|}{$\begin{array}{l}\text { Концентрація селену в сироватці } \\
\text { крові, мкг/л } \\
\text { Serum selenium concentrations, } \mu \mathrm{g} / \mathrm{l}\end{array}$} \\
\hline & $\begin{array}{l}\text { Знижена, } \\
\text { менше } \\
80 \text { мкг/л } \\
\text { Low, less } \\
\text { than } 80 \text { нg/l }\end{array}$ & $\begin{array}{l}\text { Субопти- } \\
\text { мальна, 81- } \\
100 \text { мкг/л } \\
\text { Suboptimal, } \\
81-100 \text { pg/l }\end{array}$ & $\begin{array}{l}\text { Оптималь- } \\
\text { на, 101- } \\
120 \text { мкг/л } \\
\text { Optimal, } \\
101-120 \text { нg/l }\end{array}$ \\
\hline $\begin{array}{l}\text { Вузловий та } \\
\text { багатовузловий } \\
\text { колоїдний зоб } \\
\text { Nodular and } \\
\text { multinodular } \\
\text { colloid goiter } \\
(\mathrm{n}=58)\end{array}$ & $\begin{array}{l}46(79,3 \%) \\
68,3 \pm 1,8^{*}\end{array}$ & $\begin{array}{l}4(6,9 \%) \\
91,6 \pm 0,9\end{array}$ & $\begin{array}{l}8(13,8 \%) \\
108,5 \pm 9,5\end{array}$ \\
\hline $\begin{array}{l}\text { Вузлові форми } \\
\text { колоїдного зоба } \\
\text { поєднані з XАІT } \\
\text { Nodular forms } \\
\text { of colloid goiter } \\
\text { in combination } \\
\text { with chronic } \\
\text { autoimmune } \\
\text { thyroiditis } \\
(n=8)\end{array}$ & $\begin{array}{l}6(75,0 \%) \\
75,4 \pm 1,1\end{array}$ & $\begin{array}{l}2(25,0 \%) \\
92,3 \pm 1,0\end{array}$ & 0 \\
\hline $\begin{array}{l}\text { XAIT } \\
\text { Chronic } \\
\text { autoimmune } \\
\text { thyroiditis } \\
(n=7)\end{array}$ & $\begin{array}{l}6(85,7 \%) \\
77,5 \pm 1,8\end{array}$ & $\begin{array}{l}1(14,3 \%) \\
93,8 \pm 1,4\end{array}$ & 0 \\
\hline $\begin{array}{l}\text { Контрольна гру- } \\
\text { па (ехографічна } \\
\text { картина } \\
\text { незміненої щ3) } \\
\text { Control group } \\
\text { (ultrasound- } \\
\text { unchanged } \\
\text { thyroid gland) } \\
\text { (n=8) }\end{array}$ & $\begin{array}{l}4(50,0 \%) \\
62,5 \pm 1,4\end{array}$ & $\begin{array}{l}4(50,0 \%) \\
91,7 \pm 1,3\end{array}$ & 0 \\
\hline $\begin{array}{l}\text { Всього } \\
\text { Total }\end{array}$ & $62(76,5 \%)$ & $11(13,6 \%)$ & $8(9,9 \%)$ \\
\hline
\end{tabular}

Примітка: * - статистично вірогідна різничя порівняно з контрольною групою $(p<0,05)$.

Note $^{*}$ - statistically significant difference compared with the control group $(p<0,05)$. 
3 контрольною групою (ехографічно незмінена Щ3) (табл. 1), що підтверджує доцільність проведення терапії препаратами селену, як за терапевтичного, так і хірургічного лікування.

У 78 пацієнтів із захворюваннями Щ3 проведено визначення вмісту йоду в сечі. Ці пацієнти протягом 1-3 років спостерігаються в ендокринолога з приводу доброякісної вузлової

Таблиця 2. Розподіл пацієнтів із захворюваннями ЩЗ за вмістом йоду в сечі

Table 2. Distribution of patients with thyroid diseases by serum iodine content

\begin{tabular}{|c|c|c|c|}
\hline \multirow[t]{2}{*}{$\begin{array}{l}\text { Гpyna } \\
\text { Group }\end{array}$} & \multicolumn{3}{|c|}{$\begin{array}{l}\text { Концентрація йоду в сечі, мкг/л } \\
\text { Urine iodine concentrations, } \mu \mathrm{g} / \mathrm{l}\end{array}$} \\
\hline & $\begin{array}{l}\text { Низький } \\
\text { рівень, } \\
<100 \text { мкг/л } \\
\text { Low level, } \\
<100 \text { нg/l }\end{array}$ & $\begin{array}{l}\text { Стабільно } \\
\text { оптималь- } \\
\text { ний, 100- } \\
200 \text { мкг/л } \\
\text { Stably } \\
\text { optimal, } \\
100-200 \text { нg/l }\end{array}$ & $\begin{array}{l}\text { Стабільно } \\
\text { високий, } \\
\text { >200 мкг/л } \\
\text { Stably } \\
\text { high, } \\
\text { >200 } \mu \mathrm{g} / \mathrm{l}\end{array}$ \\
\hline $\begin{array}{l}\text { Вузловий та } \\
\text { багатовузловий } \\
\text { колоїдний зоб } \\
\text { Nodular and } \\
\text { multinodular } \\
\text { colloid goiter } \\
(\mathrm{n}=58)\end{array}$ & $\begin{array}{l}22(45,8 \%) \\
78,7 \pm 3,1\end{array}$ & $\begin{array}{l}17(35,4 \%) \\
141,6 \pm 2,8\end{array}$ & $\begin{array}{l}9(18,8 \%) \\
215,3 \pm 3,8\end{array}$ \\
\hline $\begin{array}{l}\text { Вузлові форми } \\
\text { колоїдного зоба } \\
\text { поєднані з XАІT } \\
\text { Nodular forms } \\
\text { of colloid goiter } \\
\text { in combination } \\
\text { with chronic } \\
\text { autoimmune } \\
\text { thyroiditis } \\
(\mathrm{n}=8)\end{array}$ & $\begin{array}{l}4(25,0 \%) \\
92,1 \pm 1,9\end{array}$ & $\begin{array}{l}9(56,3 \%) \\
167,5 \pm 4,1\end{array}$ & $\begin{array}{l}3(18,7 \%) \\
205,7 \pm 3,1\end{array}$ \\
\hline $\begin{array}{l}\text { XAIT } \\
\text { Chronic } \\
\text { autoimmune } \\
\text { thyroiditis } \\
(n=7)\end{array}$ & $\begin{array}{l}3(50,0 \%) \\
72,3 \pm 2,0\end{array}$ & $\begin{array}{l}1(16,7 \%) \\
166,4 \pm 3,4\end{array}$ & $\begin{array}{l}2(33,3 \%) \\
210,9 \pm 2,4\end{array}$ \\
\hline $\begin{array}{l}\text { Контрольна } \\
\text { група } \\
\text { (ехографічна } \\
\text { картина } \\
\text { незміненої щ3) } \\
\text { Control group } \\
\text { (ultrasound- } \\
\text { unchanged } \\
\text { thyroid gland) } \\
\text { (n=8) }\end{array}$ & $\begin{array}{l}5(62,5 \%) \\
88,7 \pm 1,2\end{array}$ & $\begin{array}{l}3(37,5 \%) \\
132,0 \pm 2,2\end{array}$ & 0 \\
\hline $\begin{array}{l}\text { Всього } \\
\text { Total }\end{array}$ & $34(43,6 \%)$ & $30(38,5 \%)$ & $14(17,9 \%)$ \\
\hline
\end{tabular}

патології ЩЗ і XАIT та відповідно мали рекомендації щодо необхідності проведення профілактики йододефіциту продуктами харчування і препаратами йоду.

Практично в половині спостережень (34 пацієнти або 43,6\%) при різних видах зобної трансформації відзначений низький рівень йодної екскреції (<100 мкг/л) (табл. 2). У 38,5\% пацієнтів виявлено стабільно оптимальне йодне забезпечення (100-150 мкг/л) і в 17,9\% - стабільно високе (>150 мкг/л).

\section{Висновок}

Йодо- та селенодефіцит стимулюють проліферативну активність тиреоцитів, що відіграє важливу роль у патогенезі зобної трансформації Щ3 і автоімунних тиреопатій. Це свідчить про необхідність проведення йодопрофілактики з періодичним контролем екскреції йоду, а також корекції лікування препаратами йоду і селену.

\section{Список використаної літератури}

1. Marine D. Iodine and Goiter. The Endocrinologist. 1996;6(6):423-26.

2. Derwahl M, Studer H. Nodular goiter and goiter nodules: Where iodine deficiency falls short of explaining the facts. Exp Clin Endocrinol Diabetes. 2001;109(5):250-60.

3. Kotwal A, Priya R, Qadeer I. Goiter and other iodine deficiency disorders: A systematic review of epidemiological studies to deconstruct the complex web [published correction appears in Arch Med Res. 2007 Apr;38(3):366]. Arch Med Res. 2007; $38(1): 1-14$

4. Hintze G, Koebberling J. Treatment of iodine deficiency goiter with iodine, levothyroxine or a combination of both Thyroidology. 1992 Apr;4(1):37-40.

5. Gärtner R, Dugrillon A, Bechtner G. Evidence that iodolactones are the mediators of growth inhibition by iodine on the thyroid. Acta Med Austriaca. 1996;23(1-2):47-51.

6. World Health Organization, International Council for Control of Iodine Deficiency Disorders \& United Nations Children's Fund ([UNICEF)[" Indicators for assessing iodine deficiency disorders and their control through salt iodization. World Health Organization. Switzerland, Geneva: WHO Press; 1994. 57 p. Available from: https://apps.who.int/iris/handle/ $10665 / 70715$.

7. Тронько МД, Кравченко ВІ, Турчин ВІ, та ін. Йодний дефіцит і стан щитовидної залози у дітей північних регіонів Київської області, що постраждали внаслідок Чорнобильської аварії. Ендокринологія. 1999;4(1):4-11. (Tronko MD, Kravchenko VI, Turchin VI, et al. Iodine deficiency and thyroid status in children from northern areas of Kyiv region affected as a consequences of the Chornobyl accident. Endokrynologia. 1999; 4(1):4-11).

8. Halpern JP, Boyages SC, Maberly GF, et al. The neurology of endemic cretinism. A study of two endemias. Brain. 1991 Apr;114(Pt 2):825-41

9. World Health Organization. Assessment of iodine deficiency disorders and monitoring their elimination: a guide for programme managers, 3rd ed. Switzerland, Geneva: WHO Press 2007. 98 p. Available from: https://apps.who.int/iris/handle/ $10665 / 43781$. 
10. Болезни щитовидной железы. Под ред. Бравермана ЛИ. Пер. с англ. Кандора ВИ, Черновой ТО. Москва: Медицина, 2000 432 c. (Thyroid disorders. Bravermann LI., ed. Kandora VI, Chernovoj TO, trans. Moskva: Medicina, 2000. 432 p.).

11. Кравченко ВI, Миронюк НІ, Турчин ВI та ін. Динаміка йодного статусу в північних областях України, що були забруднені внаслідок Чорнобильської аварії. Ендокринологія 2006;11(1):124-33. (Kravchenko VI, Myroniuk NI, Turchyn VI, et al. The dynamics of iodine status in northern oblasts of Ukraine contaminated as a result of the Chornobyl accident. Endokrynologia. 2006;11(1):124-33).

12. Kravchenko VI, Andrusyshyna IM, Luzanchuk IA, et al Association Between Thyroid Hormone Status and Trace Elements in Serum of Patients with Nodular Goiter. Biol Trace Elem Res. 2020;196(2):393-9.

13. Giray B, Arnaud J, Sayek I, et al. Trace elements status in multinodular goiter. J Trace Elem Med Biol. 2010;24(2):106-10.

14. Kravchenko VI, Luzanchuk IA, Andrusyshyna IM, et al. Study of macro- and microelement status in patients with nodular goiter residing in Kyiv region. Galician Med J. 2018;25(4):290-7.

15. Zimmermann MB, Boelaert K. Iodine deficiency and thyroid disorders. Lancet Diabetes Endocrinol. 2015;3(4):286-95.

16. Пашковська НВ. Селен і захворювання щитоподібної залози Міжнародний ендокринологічний журнал. 2015;(7(71)):89-93 (Pashkovska NV. Selenium and thyroid disorders. Mizhnarodnyi Endokrynolohichnyi Zhurnal. 2015;(7(71)):89-93).

17. Winther KH, Bonnema SJ, Cold F, et al. Does selenium supplementation affect thyroid function? Results from a randomized, controlled, double-blinded trial in a Danish population. Eur J Endocrinol. 2015 Jun;172(6):657-67.

18. Guastamacchia E, Giagulli VA, Licchelli B, et al. Selenium and Iodine in Autoimmune Thyroiditis. Endocr Metab Immune Disord Drug Targets. 2015;15(4):288-92.

19. Gheorghiu ML, Badiu C. Selenium involvement in mitochondrial function in thyroid disorders. Hormones (Athens) 2020 Mar;19(1):25-30.

20. Winther KH, Rayman MP, Bonnema SJ, et al. Selenium in thyroid disorders - essential knowledge for clinicians. Nat Rev Endocrinol. 2020 Mar;16(3):165-76.

21. Кравченко ВI, Осадців ОI, Андрусишина IM. Дослідження впливу дефіциту селену на розвиток дифузного зоба в дітей Чернігівської області. Ендокринологія. 2012;17(3):7-12. (Kravchenko VI, Osadtsiv OI, Andrusyshina IM. Study of the impact of selenium deficiency on diffuse goiter development in children of Chernigiv region. Endokrynologia. 2012;17(3):7-12).

22. Calissendorff J, Mikulski E, Larsen EH, et al. A Prospective Investigation of Graves' Disease and Selenium: Thyroid Hormones, Auto-Antibodies and Self-Rated Symptoms. Eur Thyroid J. 2015 Jun;4(2):93-8.

23. Lacka K, Szeliga A. Significance of selenium in thyroid physiology and pathology. Pol Merkur Lekarski. 2015 Jun;38(228):348-53.

24. Davis C, Javid PJ, Horslen S. Selenium deficiency in pediatric patients with intestinal failure as a consequence of drug shortage. JPEN J Parenter Enteral Nutr. 2014 Jan;38(1):115-8.

25. Rasmussen LB, Schomburg L, Köhrle J, et al. Selenium status, thyroid volume, and multiple nodule formation in an area with mild iodine deficiency. Eur J Endocrinol. 2011 Apr;164(4):585-90

26. Liu Y, Huang H, Zeng J, et al. Thyroid volume, goiter prevalence, and selenium levels in an iodine-sufficient area: a cross-sectional study. BMC Public Health. 2013;13:1153.

27. Dunn JT, Crutchfield HE, Gutekunst R, et al. Two simple methods for measuring iodine in urine. Thyroid. 1993 Summer;3(2):119-23.

28. Назаренко ИИ, Кислова ИВ, Гусейнов ТМ, и др. Флуорометрическое определение селена 2,3-диаминонафталином в биологических материалах. Журнал аналитической химии 1975;30(4):733-7. (Nazarenko II, Kislova IV, Gusejnov TM, et al. Fluorimetric determination of selenium in biological materials by 2,3-diaminonaphthalene. Journal of Analytical Chemistry. 1975;30(4):733-7)
Йодо- и селенодефицит в патогенезе зобной трансформации щитовидной железы и аутоиммунных тиреопатий (обзор литературы и результаты собственных исследований)

\section{Ю.Н. Таращенко, А.Е. Коваленко, В.И. Кравченко, Е.И. Ковзун, О.В. Симуров}

ГУ «Институт эндокринологии и обмена веществ им. В.П. Комиссаренко НАМН Украины»

Резюме. В статье описан современный взгляд на роль дефи цита йода и селена в патогенезе патологии щитовидной железь (ЩЖ), в частности ее зобной трансформации и аутоиммунных тиреопатий. Отмечена корреляция выраженности патологических изменений со степенью йододефицита. В зонах пониженного потребления йода (<50 мкг в сутки) 25-30\% населения имеют ту или иную патологию ЩЖ. Второй по частоте возникновения патологией ЩЖ является узловой зоб, частота котрого в эндемичных по зобу регионах достигает 50-70\% от всех заболеваний ЩЖ. Сочетанный дефицит йода и селена усугубляет проблему йодной недостаточности, приводит к росту частоты гипертрофических и гиперпластических процессов в ЩЖ и аутоиммунных тиреопатий. Целью работы было определение содержания йода и селена у пациентов с доброкачественной патологией ЩЖ.

Материал и методы. Обследован 81 пациент в возрасте от 19 до 69 лет, которым проводили ультразвуковое исследование ЩЖ, определяли уровень экскреции йода с мочой церий-арсенитным методом в модификации J.T. Dunn и др. и уровень селена в сыворотке крови спектрофлюориметрическим методом. Результаты. У 43,6\% пациентов при разных видах зобной трансформации, коллоидном пролиферирующем зобе, аутоиммунных тиреопатиях и их сочетании отмечен низкий уровень йодной экскреции (<100 мкг/л); у 38,5\% пациентов выявлено стабильно оптимальное йодное обеспечение (100-150 мкг/л) и у 17,9\% пациентов - стабильно высокое (>150 мкг/л). У 76,5\% пациентов выявлен значительно сниженный уровень селена в крови (<80 мкг/л), у 13,6\% пациентов - субоптимальный (81-100 мкг/л) и только у 9,9\% пациентов - оптимальный (101-120 мкг/л). Также отмечено, что у пациентов с узловой патологией ЩЖ, аутоиммунными тиреопатиями и их сочетании, отмечен дефицит селена по сравнению с контрольной группой (эхографически неизменная ЩЖ). Вывод. Терапия препаратами йода и селена под контролем их содержания оправдана в процессе длительного наблюдения за пациентами с зобной трансформацией щЖ и аутоиммунными тиреопатиями.

Ключевые слова: йод, селен, йододефицит, узловой зоб, эндемический 30б, патология щитовидной железы, ультразвуковое исследование. 


\section{lodine and selenium deficiency in the pathogenesis of goiter transformation of the thyroid gland and autoimmune thyropathies (literature review and results of own researches)}

\section{Yu.M. Tarashchenko, A. Ye. Kovalenko, V.I. Kravchenko, O.I. Kovzun, O.V. Simurov \\ $\mathrm{SI}$ «V.P. Komisarenko Institute of Endocrinology and Metabolism of the National Academy of Medical Sciences of Ukraine»}

\begin{abstract}
The article describes a modern view on the role of iodine and selenium deficiency in the pathogenesis of thyroid diseases, in particular its goiter transformation and autoimmune thyropathies. There is a correlation between the severity of pathological changes with the degree of iodine deficiency. Endemic goiter is the most common pathology of the thyroid gland, which occurs in areas of low iodine consumption (less than 50-60 $\mu \mathrm{g}$ / day), and 25-30\% of the population has this or that thyroid pathology. The second most common pathology of the thyroid gland is nodular goiter, the frequency of which in endemic regions of the goiter reaches $50-70 \%$ of all thyroid diseases. The combined deficiency of iodine and selenium exacerbates the problem of iodine deficiency, leads to an increase in the frequency of hypertrophic and hyperplastic processes in the thyroid gland and autoimmune thyropathies. The aim of the study was to determine the content of iodine and selenium in patients with benign thyroid pathology.
\end{abstract} Material and methods. There were studied 81 patients, aged 19 to 69 years, who underwent ultrasound examination of the thyroid gland, the level of urine iodine excretion was determined by cerium-arsenic method in the J.T. Dunn et al. modification and the serum selenium level - by spectrofluorimetric method. Results. In $43.6 \%$ of patients with various types of goiter transformation, colloid proliferating goiter, autoimmune thyropathies and their combination, a low level of iodine excretion $(<100 \mu \mathrm{g} / \mathrm{l})$ was found; the stable optimal iodine supply $(100-150 \mu \mathrm{g} / \mathrm{l})$ was noted in $38.5 \%$ of patients, and $17.9 \%$ of patients had a stable high iodine supply $(>150 \mu \mathrm{g} / \mathrm{l})$. Significantly reduced levels of selenium in the blood $(<80 \mu \mathrm{g} / \mathrm{l})$ was in $76.5 \%$ of patients, suboptimal ( $81-$ $100 \mu \mathrm{g} / \mathrm{l})$ - in $13.6 \%$ of patients and optimal (101-120 $\mu \mathrm{g} / \mathrm{l})$ only in $9.9 \%$ of patients. It is also noted that in patients with nodu- lar pathology of the thyroid gland, autoimmune thyropathies and their combination, the selenium deficiency was recorded in comparison with the control group (ultrasound-unchanged thyroid gland). Conclusion. Therapy with iodine and selenium drugs under the control of their content is justified in the process of longterm monitoring of patients with goiter transformation of thyroid gland and autoimmune thyropathies.

Keywords: iodine, selenium, iodine deficiency, nodular goiter, endemic goiter, thyroid pathology, ultrasound examination.

Для цитування: Таращенко ЮМ, Коваленко АЄ, Кравченко ВІ, Ковзун ОІ, Сімуров ОВ. Йодо- та селенодефіцит у патогенезі зобної трансформації щитоподібної залози та автоімунних тиреопатій (огляд літератури та результати власних досліджень). Ендокринологія. 2020;25(4): 297-304. DOI: 10.31793/1680-1466.2020.25-4. 297.

Відомості про авторів: Юрій Миколайович Таращенко, канд. мед. наук, ORCID: 0000-0003-4787-359X; Андрій Євгенович Коваленко, д-р мед. наук, проф., ORCID: 0000-0003-0326-6421; Віктор Іванович Кравченко, д-р мед. наук, проф., ORCID: 0000-0003-08672023; Олена Ігорівна Ковзун, д-р мед. наук, проф., ORCID: 00000002-6906-6636; Сімуров Олексій Володимирович, канд. хім. наук, ORCID: 0000-0001-5413-0933.

Особистий внесок: Ю.М. Таращенко - написання фрагмента рукопису, аналіз літературних джерел, статистичний аналіз даних, відбір пацієнтів для аналізу; А.Є. Коваленко - участь у розробці концепції статті, написання фрагмента рукопису, аналіз літературних джерел; В.І. Кравченко - розробка концепції роботи, фінальне редагування статті; О.І. Ковзун - написання фрагмента рукопису, редагування статті; О.В. Сімуров — розрахунок вмісту селену та йоду в біологічних матеріалах.

Фінансування: Стаття підготовлена в рамках бюджетного фінансування Національною академією медичних наук України науково-дослідної роботи ДУ «Інститут ендокринології та обміну речовин ім. В.П. Комісаренка НАМН України» «Оптимізація діагностики хірургічного лікування та прогнозування перебігу пухлин щитоподібної залози, інциденталом надниркових залоз та паратиреоїдних аденом» (номер держреєстрації 0120U100647).

Декларація з етики: автори задекларували відсутність конфлікту інтересів і фінансових зобов'язань. 